JAROSŁAW BĄBKA

ORCID 0000-0002-8675-553X

Uniwersytet Zielonogórski

\title{
EDUKACJA WE WSPÓŁPRACY W PERSPEKTYWIENA NOWO ODCZYTYWANYCH ZAŁOŻEŃ TEORETYCZNYCH ORAZ WYZWAŃ SPOŁECZNYCH
}

\begin{abstract}
Bąbka Jarosław, Edukacja we wspótpracy w perspektywie na nowo odczytywanych zatożeń teoretycznych oraz wyzwań społecznych [Cooperative Education in Terms of Reread Theoretical Assumptions and Social Challenges]. Studia Edukacyjne nr 53, 2019, Poznań 2019, pp. 143-159. Adam Mickiewicz University Press. ISSN 1233-6688. DOI: 10.14746/se.2019.53.9

Scientific output of psychology and education studies, paradigmatic changes and social expectations form a basis for rereading the assumptions of cooperative education. The paper deals with the categories of recognizing cooperative education as an organizational form, a strategy of teaching and a model of education. The paper makes a reference to the assumptions resulting from the social-constructive paradigm, which have made it possible to present a way of thinking about cooperative education in terms of joint acquisition of knowledge and negotiating meaning. The sources of the assumptions of education were also investigated in the ideology of progressivism to show that such upbringing and education helps develop pupils' social competencies and prepares the students for functioning in a community. The considerations are completed by showing a relation between cooperative education and contemporary social challenges.
\end{abstract}

Key words: cooperative education, organizational form, strategy of education, model, educational ideology, paradigm

\section{Wprowadzenie}

Wobec przeobrażeń społecznych i ekonomicznych stawiane są pytania, jaka ludziom będzie potrzebna edukacja? Mieczysław Malewski wśród niezbędnych cech edukacji wymienia: refleksyjność, otwartość na negocjacje i poznawcze wybory, aksjologiczną heterodoksyjność, uczestnictwo jako tendencję do kontroli należną do samych uczących się podmiotów, krytycyzm związany z gotowością do reinterpretacji znaczeń i z różnych punktów wi- 
dzenia ${ }^{1}$. Choć autor o współpracy nie pisze wprost, to trudno sobie wyobrazić edukacyjny dyskurs bez negocjacji, poszukiwania wspólnych znaczeń oraz współpracy. Tak jak zmienia się świat, tak zmienia się wiedza, a także pojawiają się nowe problemy do rozwiązania na drodze negocjacji, kompromisu. Jerome Bruner doceniał znaczenie poznawania, aktywnego uczenia się oraz budowania wiedzy, ale w pracy Kultura edukacji nadał dużą rangę społeczno-kulturowym aspektom edukacji. Zdaniem autora, nową jakość w świecie może spowodować ukierunkowanie edukacji na takie kwestie, jak sprawstwo, refleksja, współpraca oraz kultura ${ }^{2}$. W niniejszym opracowaniu podjęto problem edukacji we współpracy. Uczenie się we współpracy nie jest nowym zagadnieniem pedagogicznym. Można mieć wrażenie, że wszystko w zasadzie na ten temat zostało już napisane. $W$ praktyce grupowa forma pracy wychowanków nie jest również czymś innowacyjnym. Wśród zachodnich badaczy zainteresowanie edukacją we współpracy nie słabnie, co znajduje wyraz w systematyzowaniu teoretycznego dorobku oraz prowadzeniu nowych badań ${ }^{3}$. Zastanawiające jest, że problematyka kooperacyjnego nauczania w polskiej literaturze przedmiotu nie jest doceniana. Myśl J. Brunera, że „Umysł znajduje się w głowie, ale także w interakcjach z innymi" ${ }^{4}$ inspiruje do poszukiwania relacji pomiędzy poznawczymi i społecznymi aspektami procesu kształcenia, a także dydaktycznymi i wychowawczymi wymiarami sytuacji edukacyjnych związanymi ze współpracą. Współczesne podejście do edukacji we współpracy polega na ujmowaniu aspektu poznawczego i społecznego jako dopełniających się. Koncentracja w rozważaniach na jednym aspekcie powoduje zaniedbanie drugiego i odwrotnie. W artykule, w którym wykorzystano analizę tekstów naukowych, podjęto dwa problemy. Pierwszy ukierunkowano na odczytanie idei edukacji we współpracy na nowo oraz poszukiwanie założeń w kontekście paradygmatów edukacyjnych, ideologii edukacyjnych. Drugi wiąże się z ukazaniem walorów edukacji we współpracy odnoszących się do dwóch aspektów funkcjonowania uczestników procesu kształcenia: poznawczego, związanego z gromadzeniem wiedzy oraz społecznego, dotyczącego funkcjonowania we wspólnocie ${ }^{5}$. Dzięki temu będzie można wyjść w rozważaniach o edukacji we współpracy poza instrumentalne

${ }^{1}$ M. Malewski, Od nauczania do uczenia się. O paradygmatycznej zmianie $w$ andragogice, Wrocław 2010, s. 72-73.

2 J. Bruner, Kultura edukacji, przekł. T. Brzostowska-Tereszkiewicz, Kraków 2006, s. 126.

3 P. Baepler i in., A Guide to Teaching in the Active Learning Classroom. History, Research, and Practice, Virginia 2016; F. Borsch, Kooperatives Lehren und Lernen im schulischen Unterricht, Stuttgardt 2010; J.D. Strebe, Enganing Students Using Cooperative Learning, New York 2018.

${ }^{4}$ J. Bruner, Kultura edukacji, s. 126.

${ }^{5} \mathrm{~W}$ polskiej literaturze przedmiotu istnieje całkiem pokaźny dorobek $\mathrm{w}$ tym zakresie, w którym zaznaczają się dwa nurty: dydaktyczny oraz społeczny. Podano jedynie przykładowe prace: W. Okoń, Nauczanie problemowe we wspótczesnej szkole, Warszawa 1975; M.S. Szymański, 
traktowanie jej głównie jako formy organizacji zajęć, a także sposobu wychowania i nauczania odpowiadającego kolektywistycznej organizacji życia społecznego. W rozważaniach nie ograniczono się w szczególny sposób do jakiejś konkretnej fazy życia oraz etapu kształcenia. Przyjęto Eriksonowskie myślenie o człowieku w kategoriach "dziecko w dorosłym" i „dorosły w dziecku”, co oznacza, że rozwój jednostki należy ujmować w perspektywie zdobywania kompetencji na przestrzeni życia, które umożliwiają podejmowanie kolejnych wyzwań. Już dziecko w okresie przedszkolnym oraz wczesnoszkolnym jest gotowe do uczenia się współpracy. Oznacza to, że człowiek tym okresie powinien zdobyć jak najwięcej doświadczeń związanych ze współpracą w grupie oraz poznać zasady jej organizacji, ponieważ pomiędzy 7. a 12. rokiem życia kształtują się kompetencje dotyczące współdziałania ${ }^{6}$. Umiejętność uczenia się we współpracy to zasób, z którego jednostka może korzystać w kolejnych fazach życia oraz w różnych sytuacjach.

\section{Kategorie myślenia o edukacji we współpracy}

Edukację we współpracy można rozpatrywać w trzech kategoriach: jako formę organizacyjną procesu kształcenia, strategię edukacyjną oraz model edukacji. Znajduje to odzwierciedlenie w pojęciach używanych w literaturze przedmiotu: grupowa praca uczniów ${ }^{7}$, grupowe nauczanie (kształcenie) $)^{8}$, uczenie się we współpracy ${ }^{9}$. Grupowa praca dzieci/uczniów jest jedną z form organizacyjnych procesu kształcenia, obok pracy indywidualnej i zbiorowej, która polega na wspólnym wykonywaniu zadań przez wychowanków w grupie. Funkcjonowanie pojęć grupowa praca oraz nauczanie grupowe (kształcenie grupowe) świadczy o tym, że terminy nie są tożsame. Według Bolesława Niemierki, pojęcie kształcenie grupowe oznacza strategię edukacyjną, to jest „strategię zorientowaną na uczniowski system spo-

O metodzie projektów, Warszawa 2010; H. Muszyński, Wychowanie moralne w zespole, Warszawa 1964; B. Karolczak-Biernacka, Wspótzawodnictwo i wspótpraca w szkole, Warszawa 1987.

${ }^{6}$ K. Appelt, Dziecko i dzieciństwo w oczach dorosłego, [w:] Oblicza dzieciństwa, red. D. Kornas-Biela, Lublin 2001, s. 299; K. Appelt, S. Jabłoński, Osiagnięcia i zagrożenia dla rozwoju dziecka w wieku szkolnym, [w:] Dzieci i młodzież wobec agresji i przemocy, red. A. Brzezińska, E. Hornowska, Warszawa 2004, s. 82-83.

${ }^{7}$ J. Kędzierska, Grupowa praca uczniów, [w:] Encyklopedia pedagogiczna XXI wieku, red. T. Pilch, Warszawa 2003, s. 130-133; M.S. Szymański, Grupowa praca z uczniem, [w:] Encyklopedia pedagogiczna, red. W. Pomykało, Warszawa 1993, s. 214-217.

8 A. Kamiński, Grupowe nauczanie, [w:] Encyklopedia pedagogiczna, s. 217-219; B. Niemierko, Podręcznik skutecznej dydaktyki, Warszawa 2007, s. 237-266.

${ }^{9}$ R.I. Arends, Uczymy się nauczać, przekł. K. Kruszewski, Warszawa 1995, s. 325-349; K. Kruszewski, Nauczanie i uczenie się rozwiązywania problemów, [w:] Sztuka nauczania. Czynności nauczyciela, red. K. Kruszewski, Warszawa 2005, s. 179-186. 
łeczny, na wspólnotę dydaktyczną podejmującą działanie w różnej wielkości zespołach"10. Autor w ramach strategii kształcenia grupowego wymienia następujące metody: samorządność, granie ról, narada, gra dydaktyczna, wycieczka, dyskusja, projekt badaczy, zbiorowa prezentacja i inne. W literaturze zachodniej omawia się następujące odmiany grupowego kształcenia, które mogą odpowiadać kategorii strategii edukacji: składankę, metodę badań zespołowych, metodę podwójnej oceny ${ }^{11}$. O strategii edukacyjnej, w której wykorzystuje się współpracę, można myśleć poprzez pryzmat typologii zadań, według koncepcji Ivana D. Steinera: zadań sumowalnych (addytywnych), rozłącznych (dysjunktywnych), łącznych (koniunktywnych), kompensujących, rozdzielnych (tab. 1) ${ }^{12}$. I.D. Steiner uważa, że natura zadania decyduje o tym, jakie zasoby, w tym wiedza, zdolności, umiejętności, są niezbędne do jego rozwiązania oraz osiągnięcia najlepszego z możliwych wyników, ponadto specyfika zadania wyznacza zakres współpracy ${ }^{13}$.

Typy zadań sprzyjające współpracy

Tabela 1

\begin{tabular}{|l|l|}
\hline \multicolumn{1}{|c|}{ Typ zadania } & \multicolumn{1}{c|}{ Cechy definicyjne } \\
\hline Sumowalne & $\begin{array}{l}\text { Polega na tym, aby członkowie danej grupy w toku wykonywania } \\
\text { takich samych czynności osiągnęli wynik, który będzie lepszy od } \\
\text { działania w pojedynkę. Istotne jest, aby w wyniku kooperacji doszło } \\
\text { do zsumowania wysiłku wszystkich uczestniczących osób }\end{array}$ \\
\hline Łączne & $\begin{array}{l}\text { Wymaga zaangażowania wszystkich uczestników, zarówno tych } \\
\text { najbardziej, jak i najmniej kompetentnych }\end{array}$ \\
\hline Rozłączne & $\begin{array}{l}\text { Polega na tym, aby któryś członek grupy podał jak najszybciej prawi- } \\
\text { dłowe rozwiązanie zadania }\end{array}$ \\
\hline Kompensujące & $\begin{array}{l}\text { Polega na dyskusji, podczas której wymienia się indywidualne oceny, } \\
\text { aby dojść do uzgodnienia wspólnego stanowiska }\end{array}$ \\
\hline Rozdzielne & $\begin{array}{l}\text { Polega na wyodrębnieniu w zadaniu mniejszych elementów, tzw. } \\
\text { podzadań, które są rozdzielone do wykonania pomiędzy członków } \\
\text { danej grupy }\end{array}$ \\
\hline
\end{tabular}

Źródło: opracowanie własne na podstawie: I.D. Steiner, Group Process and Productivity, New York London 1972.

Typologia pozwala traktować zadania jako środek wyzwalania współpracy dzieci/uczniów w grupie zadaniowej. Chodzi o to, aby nauczyciel świadomie formułował określone zadania, w zależności jaki stawia sobie i uczniom cel, co chce osiągnąć, czemu chce nadać znaczenie.

\footnotetext{
${ }_{10}$ B. Niemierko, Podręcznik skutecznej dydaktyki, s. 237-266.

${ }^{11}$ F. Borsch, Kooperatives Lehren, s. 37.

12 I.D. Steiner, Group Process and Productivity, New York - London 1972, s. 41-67.

${ }^{13}$ Tamże, s. 15.
} 
Znacznie głębszy sens działalności grupowej wiąże się z ujmowaniem uczenia się we współpracy w kategorii modelu edukacji. W tym ujęciu nie chodzi tylko o formalny podział uczniów na grupy, sformułowanie określonego typu zadania sprzyjającego współpracy, ale ogólniejsze założenia. Edukacja we współpracy polega na stwarzaniu warunków sprzyjających podejmowaniu przez uczniów zadań do wykonania w małych grupach, które z jednej strony sprzyjają poszukiwaniu odpowiedzi na problemy naukowe, z drugiej gromadzeniu doświadczeń związanych z życiem społecznym, stosunkami interpersonalnymi, konfliktami i negocjowaniem. Edukacja we współpracy odpowiada ideom społecznych modeli według Bruce’a Joyce’a, Emily Calhoun, Davida Hopkinsa ${ }^{14}$. Autorzy zwracają uwagę, że modele społeczne łączą aspekt dydaktyczny i wychowawczy (społeczny) sytuacji edukacyjnych. Związek frazeologiczny z pojęciem społeczny nie oznacza, że te modele bagatelizują proces kształcenia związany $\mathrm{z}$ gromadzeniem wiedzy:

Modele społeczne pomagają nauczyć się jak kształtować proces uczenia się dzięki
kontaktom z innymi osobami, jak wydajnie współpracować z ludźmi o różnym cha-
rakterze i usposobieniu (...). Co zaś się tyczy rozwoju intelektualnego i opanowania
treści nauczania, modele ułatwiają przyjęcie cudzej - indywidualnej albo grupowej
perspektywy, jaśniej i szerzej myśleć, ujmować własne myśli w pojęcia ${ }^{15}$.

Edukacja we współpracy pozwala w jakiś sposób „poprawiać świat” poprzez uwzględnianie ważnych dla wspólnoty kwestii, na przykład funkcjonowania według demokratycznych reguł, doświadczania i rozwiązywania nabrzmiałych problemów społecznych, likwidowania uprzedzeń, przeciwdziałania wykluczeniu i tym podobnych. Warto podkreślić, że edukacja we współpracy daje sposobność oddziaływania zarówno na sferę poznawczą, jak i społeczną wychowanków. Dzięki temu jest możliwe rozwijanie u edukowanych osób kompetencji poznawczych oraz społecznych. Kompetencje poznawcze dotyczą refleksyjności, decentracji, planowania czynności, podejmowania decyzji, wspólnego dochodzenia do wiedzy, negocjowania znaczeń. Z kolei kompetencje społeczne uwzględniają empatię, komunikowanie się, negocjowanie, myślenie w kategoriach "My”, funkcjonowanie według demokratycznych (wynegocjowanych) reguł, otwartość na innych ludzi ${ }^{16}$.

${ }^{14}$ B. Joyce, E. Calhoun, D. Hopkins, Przykłady modeli uczenia się i nauczania, przekł. K. Kruszewski, Warszawa 1999, s. 37-46.

${ }^{15}$ Tamże, s. 107.

16 Tamże, s. 41-42. 


\section{Edukacja we współpracy w kontekście założeń paradygmatu społeczno-konstruktywistycznego}

Pojęcie paradygmat naukowy spopularyzowane przez Thomasa S. Kuh$\mathrm{na}^{17}$ stanowi kategorię trudną do wykorzystania w pedagogice ze względu na odmienny od nauk przyrodniczych rodzaj analizowanych zjawisk. Istnieją autorzy, którzy dostrzegają kategorię paradygmatu za użyteczną w pedagogice, $w$ tym teorii kształcenia. Traktowanie paradygmatu jako zbioru ogólnych i ostatecznych przesłanek w wyjaśnieniu jakiegoś obszaru rzeczywistości, a następnie upowszechnionych ich jako wzoru myślenia przez przedstawicieli danej dyscypliny naukowej ${ }^{18}$ może być rzeczywiście użyteczne. Różne odmiany dydaktyki są wynikiem odwoływania się do odmiennych założeń ontologicznych, epistemologicznych, socjologicznych, psychologicznych ${ }^{19}$. W literaturze przedmiotu funkcjonują różne ujęcia paradygmatów, na przykład paradygmat nauczania podającego i poszukującego, odtwórczo-transmisyjnego i twórczego, dydaktyka scjentystyczna jako techniczno-instrumentalna i humanistyczna, dydaktyka obiektywizmu i dydaktyka subiektywizmu, paradygmat kształcenia pozytywistycznego i krytycznego, edukacyjna ",teorię wpływu" jako przekazu i teoria rozwoju przedstawiona w formule konstruktywistycznej ${ }^{20}$. Wynika z tego, że paradygmaty przedstawia się jako spolaryzowane oraz konkurujące ze sobą. Bogusław Śliwerski ${ }^{21}$ uważa, że pedagogika jest nauką wieloparadygmatyczną. Według Joanny Rutkowiak22, wbrew sformułowanym opozycjom, w działaniach nauczycieli wyrażają się różne paradygmaty. Odczytanie na nowo edukacji we współpracy wiąże się z koniecznością odwołania się do wiedzy paradygmatycznej, co pozwoli wyjść w rozważaniach poza ujmowanie jej jedynie w kategorii formy organizacji zajęć, strategii edukacji, czy modelu edukacji. Przyjęto, że założeń edukacji we współpracy można poszukiwać w koncepcji paradygmatów według

17 T. Kuhn, Struktura rewolucji naukowych, przekł. H. Ostromęcka, Warszawa 2001, s. 27.

${ }_{18}$ Z. Kwieciński, Mimikra czy sternik? Dramat pedagogiki w sytuacji przesilenia formacyjnego, [w:] Spory o edukację: dylematy i kontrowersje we wspótczesnych pedagogiach, red. Z. Kwieciński, L. Witkowski, Warszawa-Torun, s. 18.

19 D. Klus-Stańska, Dydaktyka wobec chaosu i pojęć zdarzeń, Warszawa 2010, s. 34.

${ }^{20}$ T. Hejnicka-Bezwińska, Paradygmat pedagogiki instrumentalnej w Polsce (Skutki jego dominowania w badaniach pedagogicznych $i$ kształceniu pedagogoów), [w:] Ku pedagogii pogranicza, red. Z. Kwieciński, L. Witkowski, Torun 1990, s. 158-176; J. Oelkers, Influence and Development: Two Basic Paradigms of Education, Studies in Philosophy and Education, 1994, 2, s. 91-109.

${ }^{21}$ B. Śliwerski, Wspótczesna myśl pedagogiczna. Znaczenia, klasyfikacje, badania, Kraków 2009, s. 31 .

${ }^{22}$ J. Rutkowiak, Wielość paradygmatów dydaktyki a wspólny mianownik realności życia. Ku pytaniom o przekłady międzyparadygmatyczne, [w:] Paradygmaty współczesnej dydaktyki, red. L. Hurło, D. Klus-Stańska, M. Łojko, Kraków 2009, s. 28. 
Doroty Klus-Stańskiej. Autorka wyróżniła paradygmat behawiorystyczno-funkcjonalistyczny, humanistyczno-adaptacyjny, konstruktywistyczno-psychologiczny oraz konstruktywistyczno-społeczny ${ }^{23}$. Dorota Klus-Stańska, znawczyni problematyki, wyjaśnia, że w poglądach konstruktywizmu społecznego widoczne są różnice $w$ jego początkowych i późniejszych wersjach: „W nowszych wersjach dyskursu konstruktywistyczno-społecznego miejsce nauczyciela zajmuje coraz częściej rówieśnik (niekoniecznie bardziej kompetentny)", co zgodnie z tradycją Deweyowskiego postulatu edukacji dla demokracji przyczyniło się do zastępowania nauczyciela "przez inicjatywę intelektualną zespołu rówieśniczego" ${ }^{24}$. Stanowi to bardzo ważne uzasadnienie dla edukacji we współpracy w kontekście założeń konstruktywizmu społecznego. Każdy uczący się konstruuje i rekonstruuje swoją wiedzę, zamiast przyjmować ją z autoryzowanych źródeł, takich jak nauczyciel czy podręcznik ${ }^{25}$. Bogusława D. Gołębniak przestrzega przed instrumentalizowaniem konstruktywizmu. Warto doceniać znaczenie obecności rówieśników w procesie strukturyzowania i restrukturyzowania wiedzy, ale sama praca $\mathrm{w}$ grupach nie przesądza o nadawaniu i negocjowaniu znaczeńn ${ }^{26}$. Interakcje $\mathrm{z}$ innymi osobami są dla wychowanków środkiem negocjowania znaczeń, poszerzania wiedzy oraz umiejętności. O konstruktywistycznej edukacji można mówić wówczas, kiedy ma w niej miejsce: (1) tworzenie sytuacji edukacyjnych, które stanowią wyzwanie dla aktualnego poziomu rozwoju wychowanków oraz wywołują u nich konflikt poznawczy wzbudzający zdziwienie i prowokujący do działania, (2) aktualizowanie i poszerzanie zasobów wiedzy, (3) angażowanie się $\mathrm{w}$ proces analizowania i rozwiązywania problemów, które nie są dla uczniów błahe, a jednocześnie dotyczących różnych dziedzin nauki i życia człowieka, (4) tworzenie okazji do podejmowania działania w grupie, co sprzyja wymianie myśli, poznawaniu różnych punktów widzenia, wspólnemu rozwiązywaniu problemów, (5) występowanie nauczyciela

${ }^{23}$ D. Klus-Stańska, Polska rzeczywistość - paradygmatyczny taniec św. Wita, [w:] Paradygmaty współczesnej dydaktyki, red. L. Hurło, D. Klus-Stańska, M. Łojko, Kraków 2009, s. 62-73.

24 Paradygmat konstruktywistyczno-społeczny znajduje swoje uzasadnienie w pracach Lva S. Wygotskiego oraz Jeromiego Brunera, którzy pomimo różnic koncepcyjnych traktowali uczenie się jako aktywny proces społeczno-kulturowy dziecka w interakcji z innymi osobami. Z prac L.S. Wygotskiego wynika, że w procesie uczenia się dziecka ważna jest rola bardziej kompetentnego dorosłego. Z kolei J. Bruner doceniał znaczenie rówieśników w edukacji. Zob. D. Klus-Stańska, Polska rzeczywistość dydaktyczna, s. 71; taże, Dyskursy pedagogiki wczesnoszkolnej, [w:] Pedagogika wczesnoszkolna - dyskursy, problemy, rozwiązania, red. D. Klus-Stańska, M. Szczepska-Pustkowska, Warszawa 2012, s. 65-67.

25 W.M. Rotch, Experimenting in a constructivist high school physics laboratory, Journal of Research in Science Teaching, 1994, 31, s. 197-223.

26 B.D. Gołębniak, Konstruktywizm - moda, "nowa religia” czy tylko/aż interesująca perspektywa poznawcza i dydaktyczna, Problemy Wczesnej Edukacji, 2005, 1, s. 13-20. 
w roli współuczestnika działań, (6) tworzenie atmosfery współpracy, która sprzyja tworzeniu zasad społeczno-moralnych regulujących funkcjonowanie w grupie, rozwiązywaniu konfliktów ${ }^{27}$. Edukacja w takim ujęciu odpowiada wyróżnionemu przez Jeromego Brunera modelowi rozwoju wymiany intersubiektywnej i polega na pomocy uczniowi w lepszym, mniej jednostronnym rozumieniu wiedzy poprzez dyskusję, współpracę, zachęcenie do wyrażenia swoich poglądów, co prowadzi do porozumienia z innymi, którzy reprezentują inne punkty widzenia ${ }^{28}$. Bogusława Gołębniak uważa, że sam konstruktywizm pozwala lepiej zrozumieć mediowanie $w$ procesie dochodzenia do wiedzy niż oferuje wizję świata społecznego ${ }^{29}$. Poglądy J. Brunera przełamują to ograniczenie. Anna I. Brzezińska, znawczyni twórczości J. Brunera, uważa, że poglądy autora trzeba ujmować w kontekście przemian w jego myśleniu, które nie były już tylko ukierunkowane na sam proces uczenia się i wiedzę, ale społeczno-kulturowe aspekty edukacji oraz demokratyzację życia społecznego $^{30}$. J. Bruner ujmuje edukację w kontekście takich zjawisk, jak: refleksyjność, sprawstwo, współpraca i kultura. Refleksyjność wiąże się z pojmowaniem sensu, uczeniem się ze zrozumieniem. Sprawstwo dotyczy większego zaangażowania oraz własnej aktywności wychowanków, zaś kultura stanowi sposób życia, myślenia, który jest konstruowany, negocjowany i instytucjonalizowany. Współpraca to aktywność, która sprzyja dialogowi i dyskursowi z "Innymi”, pozyskiwaniu informacji od ludzi o sobie oraz dzieleniu się wiedzą. J. Bruner, podobnie jak J. Dewey oraz progresywiści, uważa, że świat nie jest gotowy i skończony ${ }^{31}$. Wyzwaniem dla edukacji jest podtrzymywanie demokratyczności kultury, a problemy dotyczące płci, rasy, religii, pochodzenia etnicznego, inności można rozwiązywać poprzez debatę, negocjację i współpracę $e^{32}$. Stanisław Dylak dostarczył argumentacji, że konstruktywizm jest nurtem, który pozwala wprowadzić do klasy zwątpienie u wychowanków oraz postawę otwartości i poszukiwania, a także niezależność poznawczą w sferze moralnej ${ }^{33}$.

${ }^{27}$ M. Kowalik-Olubińska, Pedagogiczne implikacje założeń konstruktywizmu dla edukacji matych dzieci, [w:] Zaniedbane i zaniechane obszary edukacji w szkole, red. M. Suświłło, Olsztyn 2006, s. 361-364.

${ }^{28}$ J. Bruner, Kultura edukacji, s. 86-92.

${ }^{29}$ B. Gołebniak, Konstruktywizm - moda, nowa religia, s. 19-20.

30 A. Brzezińska, J. Bruner, Prekursor ksztatcenia wspomagającego rozwój, [w:] Kultura edukacji, Kraków 2006, s. XVII.

31 J. Bruner, Kultura edukacji, s. 140.

${ }^{32}$ Tamże, s. 138.

${ }^{33}$ S. Dylak, Konstruktywizm jako obiecująca perspektywa w ksztatceniu nauczycieli, [w:] Wspótczesność a ksztatcenie nauczycieli, red. H. Kwiatkowska, T. Lewowocki, S. Dylak, Warszawa 2000, s. 78-79. 


\section{Ideologia progresywizmu jako źródło założeń edukacji we współpracy}

Przyjmując, że ideologia edukacyjna oznacza usystematyzowane połączenie teorii psychologicznych, społecznych faktów oraz zasad aksjologicznych, można odnieść się do trzech ideologii: romantycznej, transmisji kulturowej oraz progresywizmu ${ }^{34}$. Najbliższa założeniom edukacji we współpracy jest ideologia progresywizmu. Zdaniem Allana C. Ornseina oraz Francisa P. Hunkinsa:

Progresywizm zwracał się ku dziecku i ku uczniowi, nie ku treści przedmiotowej, ku działaniu i doświadczaniu, nie ku werbalizmowi, wybierał grupowe uczenie zamiast rywalizacji między uczniami i jednostkowego uczenia się podczas lekcji zbiorowych. Traktował oparcie szkoły na zasadach demokratycznych jako wstęp do reformy społecznej i demokratyzacji lokalnego środowiska ${ }^{35}$.

Z tej ideologii edukacji wynika, że w procesie uczenia się ważne jest działanie, rozwiązywanie problemów oraz konfliktów, gromadzenie doświadczeń sprzyjających budowaniu wiedzy, która powoduje aktywną zmianę we wzorach myślenia wychowanków. Według Johna Deweya i jego kontynuatorów, wiedza nie istnieje niezależnie od człowieka, co oznacza, że jest niejako konstruowana przez niego poprzez fakty, doświadczenia oraz działanie. Edukacja dla progresywistów jest procesem rekonstruowania doświadczeń, $\mathrm{w}$ sytuacjach, kiedy uczniowie sami albo $\mathrm{w}$ grupie rozwiązują problemy. Proces uczenia się ma polegać na rekonstrukcji osobistego i społecznego doświadczenia, a doświadczenia - w relacji zwrotnej - stanowić mają infrastrukturę uczenia się $e^{36}$. Dla niniejszych rozważań ważne jest, że w progresywizmie ujmuje się związek pomiędzy rozwojem poznawczym i moralnym wychowanków. W zależności od tego jakie uczniowie rozwiązują problemy oraz gromadzą doświadczenia, tak przebiega ich rozwój społeczno-moralny. Wynika z tego, że rozwój moralny wyrasta z interakcji społecznych w sytuacjach konfliktu społecznego ${ }^{37}$.

${ }^{34}$ L. Kohlberg, R. Mayer, Rozwój jako cel wychowania, [w:] Spory o edukację. Dylematy i kontrowersje we wspótczesnych pedagogiach, red. Z. Kwieciński, L. Witkowski, Warszawa 1993, s. 51-93.

35 A.C. Ornstein, F.P. Hunkins, Program szkolny. Założenia, zasady, problematyka, przekł. K. Kruszewski, Warszawa 1999, s. 74.

36 J. Dewey, Demokracja i wychowanie, przekł. Z. Dorszowa, Wrocław 1972, s. 58, 199, 370; Z. Melosik, Pedagogika pragmatyzmu, [w:] Pedagogika. Podręcznik akademicki, t. 1, red. Z. Kwieciński, B. Liwerski, Warszawa 2003, s. 311; A.C. Ornstein, F.P. Hunkins, Program szkolny, s. 60-61.

37 L. Kohlberg, R. Mayer, Rozwój jako cel wychowania, s. 56. 
Gdy wartość jest zweryfikowana pozytywnie w trakcie inteligentnego, refleksyjnego działania, wówczas może być uznana za "korzystny standard moralny”, przy czym trzeba dodać, że „filozofia moralna powinna być przedmiotem permanentnej rekonstrukcji" ${ }^{38}$.

Współcześni autorzy nawiązujący do założeń progresywizmu zwracają uwagę, że osiąganie moralności jest wynikiem raczej aktywnej zmiany we wzorach reakcji na problemowe sytuacje społeczne niż $\mathrm{z}$ efektem uczenia się kulturowo zaakceptowanych ról ${ }^{39}$. W związku z tym, tak jak zmienia się świat i zmieniają się uczniowie, tak powinny się zmieniać sposoby ich edukacji oraz treści nauczania. W tym kontekście edukacja we współpracy bardzo dobrze wpisuje się w założenia ideologii edukacyjnej progresywizmu. Wśród zarzutów wobec progresywistów znajduje się lekceważenie wiedzy oraz nacisk na wiedzę praktyczną. W tym kontekście trzeba przywołać A.C. Orsteina oraz F.P. Hunkisa, którzy twierdzą, że John Dewey krytykował progresywistycznych ekstremistów za fałszywe interpretacje oraz niedocenianie wiedzy w procesie kształcenia: „Jeśli progresywizm pójdzie dalej tą drogą i nie zmieni celów, wpadnie w pułapkę i zostanie z tyłu" ${ }^{40}$. Wypowiedź świadczy o tym, jak ważne jest równoważenie edukacji we współpracy aspektu poznawczego i społecznego, jednostkowego i wspólnotowego, emancypacyjnego i socjalizacyjnego.

\section{Edukacja we współpracy w kontekście współczesnych wyzwań społecznych}

$\mathrm{Na}$ problem edukacji we współpracy warto spojrzeć z perspektywy oczekiwań społecznych. Chodzi to, że konsekwencje działań edukacyjnych mają charakter bliski i daleki. Wiąże się to z koniecznością odczytania wyzwań społecznych, które można zrealizować dzięki edukacji we współpracy. W kontekście wyzwań społecznych można wymienić następujące argumenty uzasadniające edukację we współpracy: (1) przechodzenie do gospodarki opartej na wiedzy, (2) budowanie kapitału społecznego, (3) zmiany od środka polskiej szkoły. Nie znaczy, że nie można zaproponować innych kierunków poszukiwań. Polska nie weszła jeszcze w erę gospodarki opartej na wiedzy, która swoją konkurencyjność zawdzięcza potencjałowi intelektualnemu

${ }^{38}$ E.J. Power za: Z. Melosik, Pedagogika pragmatyzmu, [w:] Pedagogika. Podręcznik akademicki, t. 1, red. Z. Kwieciński, B. Śliwerski, Warszawa 2003, s. 311.

${ }^{39}$ L. Kohlberg, R. Mayer, Rozwój jako cel wychowania, s. 56; R. Rorty, Filozofia a nadzieja na lepsze społeczeństwo, przekł. J. Grygieńć, S. Tokariew, Toruń 2013, s. 289-298.

${ }^{40}$ A.C. Ornstein, F.P. Hunkins, Program szkolny, s. 73. 
pracowników oraz która charakteryzuje się innowacyjnością rozwiązań ${ }^{41}$. Innowacyjność w gospodarce opartej na wiedzy jest wynikiem działania zespołowego. W krajach wysokorozwiniętych, które weszły już w erę gospodarki opartej na wiedzy, liczy się innowacyjność, twórczość oraz kooperacja. Szybkie tempo przemian powoduje, że wiedza zmienia się w krótkim czasie. Jednak sama wiedza nie przyczynia się do wzrostu gospodarczego, trzeba znaleźć sposób jej wykorzystania. Niezbędna jest odpowiednia organizacja, która dzięki wzajemnej komunikacji, bogatym więziom i współpracy, powiązaniom sieciowym i nowym technologiom informacyjnym umożliwia zastosowanie wyspecjalizowanej wiedzy ${ }^{42}$. Wspieranie gospodarki opartej na wiedzy odbywa się poprzez przemyślaną politykę edukacyjną poprawiającą jakość kształcenia oraz poszukiwanie skutecznych sposobów uczenia się. Według dalekosiężnej wizji Edukacji 2050 Stephana Downesa,

nauczanie będzie ustawicznym procesem opartym na dzieleniu się wiedzą przez ludzi bez względu na wiek i etap kształcenia. Uczenie się będzie strumieniem (wiedza praktyczna, często aktualizowana i odnawiana), nie zaś tworzeniem zamkniętego zasobu (tzw. zbiornika retencyjnego), z którego korzystamy przez całe życie ${ }^{43}$.

W innych pracach pisze się o tak zwanych grupowych transgresjach, zbiorowym rozumie. Konkurencyjność gospodarki, innowacyjne rozwiązania, walka z chorobami to przykłady problemów, które wymagają wspólnego zaangażowania, zbiorowego rozumu, grupowych transgresji, współpracy $\mathrm{w}$ dochodzeniu do nowej wiedzy ${ }^{44}$.

Wśród czynników sprzyjających rozwojowi gospodarki opartej na wiedzy wymienia się również kapitał społeczny, który wiąże się z zaufaniem społecznym, dobrymi relacjami społecznymi, zaangażowaniem społecznym i współpracą. Janusz Czapiński dostarczył empirycznych dowodów, że „Kapitał społeczny nie odgrywa żadnej roli w rozwoju gospodarczym w krajach ubogich, natomiast w krajach bogatych ma znaczenie decydujące" ${ }^{45}$. Autorzy Diagnozy Społecznej twierdzą, że jako społeczeństwo „Jesteśmy w fazie rozwoju molekularnego, charakterystycznego dla krajów słabo rozwiniętych

${ }^{41}$ A. Koźmiński, Jak tworzyć gospodarkę oparta na wiedzy? [w:] Strategia rozwoju Polski u progu XXI wieku, Warszawa 2001, s. 87.

${ }^{42}$ P.F. Drucker, Społeczeństwo pokapitalistyczne, przekł. G. Karnas, Warszawa 1999, s. 74-77.

${ }^{43}$ S. Downes za: A.I. Brzezińska, B. Ziółkowska, Przed jakimi wyzwaniami stoi dzisiaj szkoła, Studia Edukacyjne, 2013, 27, s. 38.

${ }^{44}$ Badania eksperymentalne dowodzą, że umysł grupowy jest inteligentniejszy niż indywidualny. G.W. Hill, Group Versus Individual Perfomance: Are N+1 Heads Better Than One? Psychological Bulletin, 1982, 91, s. 517-539; J. Henrich, The Secret of Our Success. How Culture Is Drving Human Evolution, Domesticating Our Species, and Making Us Starter, New Jersey 2016.

${ }_{45}$ J. Czapiński, Kapitał społeczny jako motor rozwoju rozwiniętych, Małopolskie Studia Regionalne, 2010, 1(18), s. 29-36. 
- w opozycji do rozwoju wspólnotowego, charakterystycznego dla krajów wysoko rozwiniętych". Badacze dostrzegają w polskim społeczeństwie takie niepokojące zjawiska, jak zanik więzi społecznych, niski poziom zaufania, społeczne wykluczenie czy małe obywatelskie zaangażowanie ${ }^{46}$. Janusz Czapiński uważa, że „(...) powinniśmy czym prędzej szukać sposobów (...), jak zwiększyć społeczne zaufanie, gotowość do współpracy i zdolność do zawierania kompromisów" ${ }^{\prime 7}$. Zdaniem autorów Diagnozy Społecznej,

zostało nam niewiele lat na zbudowanie kapitału społecznego, jeśli chcemy się dalej rozwijać. Dla powodzenia przedsięwzięć zbiorowych, wymagających efektywnej współpracy (...) lokalnych społeczności i poszczególnych obywateli niezbędny jest kapitał społeczny: wiedza i zdrowie przestają wystarczać ${ }^{48}$.

Rodzi się w tym kontekście pytanie o związek analizowanego problemu ze współpracą? Kapitał społeczny można uruchomić poprzez współpracę. James Coleman oraz Robert D. Putnam myślą o kapitale społecznym poprzez zaufanie, normy i powiązania, które sprzyjają kooperacji i efektywności grupowego działania ${ }^{49}$ : „Im większy poziom zaufania w obrębie społeczności, tym większe prawdopodobieństwo współpracy. Z kolei współpraca powiększa zaufanie ${ }^{\prime 50}$. Autorzy są zgodni, że miejscem sprzyjającym budowaniu kapitału społecznego oraz rozwijaniu umiejętności współpracy jest szkoła. Niestety, współczesna szkoła nie realizuje wyzwań dotyczących edukacji dla przyszłości oraz sama wymaga zmian. Maria Dudzikowa na podstawie badań przekonuje: „Jeszcze nigdy nie byliśmy w takiej sytuacji, kiedy to właśnie pytanie o kapitał społeczny i perspektywy jego rozwoju w środowisku szkolnym miało tak wielką rangę jak obecnie" ${ }^{\prime 51}$. Niestety, z badań autorki wynika, że szkoła nie umożliwia wychowankom gromadzenia doświadczeń prospołcznych, o czym świadczą małe szkolne zasoby kapitału społecznego

46 J. Czapiński, Kapitał społeczny, [w:] Diagnoza społeczna. Warunki i jakość życia Polaków 2013, red. J. Czapiński, T. Panek, Warszawa 2013, s. 321-331; tenże, Kapitat społeczny, [w:] Diagnoza społeczna. Warunki i jakość życia Polaków 2015, red. J. Czapiński, T. Panek, Warszawa 2015, s. 353-363.

47 J. Czapiński, Kapitał społeczny, [w:] Diagnoza społeczna. Warunki i jakość życia Polaków 2007, red. J. Czapiński, T. Panek, Warszawa 2007, s. 74.

48 J. Czapiński, Kapitał społeczny, [w:] Diagnoza społeczna. Warunki i jakość życia Polaków 2013, s. 323-331.

${ }^{49}$ J. Coleman, za: M. Kwiatkowski, M. Theis, Kapitał społeczny. Od metafory do badań, Rocznik Lubuski, 2004, 30, s. 15; R.D. Putnam, Demokracja w działaniu. Tradycje obywatelskie we wspótczesnych Włoszech, przekł. J. Szacki, Kraków 1995, s. 258.

50 Tamże, s. 265.

51 M. Dudzikowa, Erozja kapitału społecznego w szkole w atmosferze nieufności, [w:] Kapitał społeczny w szkołach różnego szczebla. Diagnoza i uwarunkowania, t. 2, red. M. Dudzikowa, S. Jaskulska, R. Wawrzyniak-Beszterda, E. Bochno, I. Bochno, K. Knasiecka-Falbierska, M. Marciniak, Kraków 2011, s. 42. 
w wymiarze społecznego zaangażowania. Szkoła nie stwarza możliwości aktywności w sferze publicznej, swobodnego wyrażania własnych opinii na łamach mediów szkolnych, czy praktycznego uczestniczenia w nauce współrządzenia, demokracji, współdziałania społecznego, czy współodpowiedzialności. Niepokojące jest, że nauczyciele cenią bardziej rygor, dyscyplinę i posłuszeństwo uczniów. Zachwiana jest też równowaga pomiędzy Ja i My poprzez poddawanie uczniów presji rywalizacji i indywidualnego sukcesu ${ }^{52}$. $\mathrm{Z}$ badań wynika, że uczenie się we współpracy nie należy do metod często wykorzystywanych w edukacji, pomimo jej wielu walorów. Badania Bożeny Pawlak świadczą o niskiej częstotliwości wykorzystywania pracy grupowej uczniów w edukacji wczesnoszkolnej. Biorąc pod uwagę, że dzieci na tym etapie rozwoju i edukacji wymagają częstego treningu w zakresie współpracy, to częste wykorzystanie pracy grupowej deklaruje jedynie $4,4 \%$ respondentów ${ }^{53}$. Niski wskaźnik procentowy wykorzystania grupowej aktywności uczniów odnotowano w przypadku liceów ogólnokształcących (10\%), nieco wyższy dotyczy szkół podstawowych $(21,8 \%)$. Pracę w grupie na niektórych zajęciach wykorzystuje się $\mathrm{w}$ technikach $(67,4 \%)$ i zasadniczych szkołach zawodowych $(67,2 \%)$, co prawdopodobnie wiąże się z pracą uczniów nad praktycznymi projektami ${ }^{54}$. Według $20,7 \%$ uczniów w szkołach gimnazjalnych z oddziałami integracyjnymi nauczyciele bardzo rzadko wykorzystują pracę $\mathrm{w}$ grupach, natomiast 54,3 \% wychowanków twierdzi, że ta forma edukacji jest stosowana bardzo rzadko. Jest to wysoce niezadowalająca tendencja $\mathrm{z}$ tego względu, że uczenie się we współpracy sprzyja spójności grupy, a także pozwala likwidować uprzedzenia wobec wszelkich inności ${ }^{55}$. Istnieją dowody na temat skuteczności uczenia się we współpracy pod kątem psychospołecznego funkcjonowania wychowanków na różnych poziomach kształcenia. Nauczanie kooperatywne sprzyja opanowaniu przez uczniów wiedzy i umiejętności, wyższemu poziomowi rozumowania, twórczemu myśleniu i tym podobnych ${ }^{56}$. Ponadto, współpraca podnosi samoocenę, za-

${ }_{52}$ M. Dudzikowa, Ku sprawstwu, wspótpracy i refleksyjności poprzez ich doświadczanie w edukacji szkolnej. Brunerowskie przestanie w praktyce, [w:] Doświadczenia szkolne pierwszego rocznika edukacji, red. M. Dudzikowa, R. Wawrzyniak, Kraków 2011, s. 337-413.

${ }_{53}$ B. Pawlak, Praca grupowa w edukacji wczesnoszkolnej. Problemy - badania - rozwiazania, Kraków, s. 53-54.

${ }^{54}$ S. Babula i in., Nauczanie kooperatywne (uczenie się we wspótpracy) https://www.npseo/ pldata/various,files/Sesja\%2011_9\%20Jakub\%20Kołodziejczyk.pdf.

${ }_{55} \mathrm{~J}$. Bąbka, Zachowania kooperacyjne w sytuacjach zadaniowych u młodzieży w okresie wczesnej adolescencji. Analiza porównawcza młodzieży petnosprawnej i z różnymi ograniczeniami sprawności, Zielona Góra 2012, s. 133.

56 D.W. Johnson, R.T. Johnosn, Cooperation and Competition: Theory and Research, Edina Minnesota 1989, s. 39, 55, 80; R.M. Gillies, Cooperative Learning. Integrating Theory and Practice, Los Angeles - London - New Delhi - Singapore 2007, s. 79. 
ufanie do innych, zmniejsza agresję, sprzyja spójności oraz integracji grupy wychowanków ${ }^{57}$. W dobrze pojmowanej, zgodnie z założeniami społecznego konstruktywizmu oraz progresywizmu, a także realizowanej edukacji można upatrywać szans na zmianę kultury szkoły poprzez równoważenie skrajności dotyczących takich zjawisk, jak rywalizacja vs współpraca, indywidualizm vs wspólnotowość, emancypacja vs socjalizacja.

\section{Podsumowanie}

We współczesnej pedagogice zaznacza się wielość paradygmatów oraz związanych z nimi sposobów myślenia o edukacji, którym odpowiadają różne praktyki. Edukacja we współpracy, pomimo jej wielu walorów, nie powinna stanowić jedynie słusznego modelu wychowania i nauczania. Niemniej, wybór takiego sposobu edukacji powinien wiązać się ze świadomością teoretycznych aplikacji, jak i bliższych oraz dalszych konsekwencji podejmowanych działań. W tym kontekście zasadne było poszukiwanie założeń na poziomie paradygmatów, ideologii oraz modeli edukacyjnych. Każdy paradygmat edukacyjny, jak twierdzi Zbigniew Kwieciński, ma w swojej strukturze ideologię, epistemologię, teorię socjologiczną, psychologiczną, swoisty sposób rozumienia zjawisk oraz podejście do zmian społecznych ${ }^{58}$, co znajduje odbicie we wzorze myślenia o edukacji. Przekonuje mnie podejście D. Klus-Stańskiej, aby nie mieszać teoretycznych podejść. Natomiast, można zastanawiać się, kiedy jest możliwe tak zwane dialogowanie pomiędzy paradygmatami, stanowiskami teoretycznymi, co pozwala na przekład, wymianę, dopełnianie określonych elementów ${ }^{59}$. W tym kontekście wydawało się zasadne ukazanie źródeł założeń edukacji we współpracy wynikających z paradygmatu konstruktywistyczno-społecznego oraz ideologii progresywizmu. Dzięki temu można było ukazać walory edukacji we współpracy dotyczące aspektu poznawczego i społecznego, dydaktycznego i wychowawczego. D.C. Phillips oraz J.F. Soltis uważają, że prace konstruktywistów oraz progresywistów, między innego J. Brunera oraz J. Deweya, stanowią podstawę do tego, że „myślenie, uczenie się i rozwiązywanie problemów to procesy, których nie można rozpatrywać wyłącznie w odniesieniu do mózgu"60. Według autorów,

${ }^{57}$ F. Borsch, Kooperatives Lehren und Lernen, s. 90-100; R.M. Gillies, Cooperative Learning, 2007, s. 29-59.

${ }^{58}$ Z. Kwieciński, Socjopatologia edukacji, Olecko-Białystok 1995, s. 66.

59 D. Klus-Stańska, Dyskursy pedagogiki wczesnoszkolnej, [w:] Pedagogika wczesnoszkolna - dyskursy, problemy, rozwiazania, red. D. Klus-Stańska, M. Szczepska-Pustkowska, Warszawa 2012, s. 65-67.

${ }^{60}$ D.C. Phillips, J.F. Soltis, Podstawy wiedzy o nauczaniu, przekł. E. Jusewicz- Kalter, Gdańsk 2003 s. 95. 
dobry nauczyciel konstruktywista nie będzie się różnił od nauczyciela progresywisty, ponieważ jeden i drugi stworzy warunki, aby uczniowie w trakcie współpracy aktywnie poszukiwali odpowiedzi na problemy, dyskutowali, zastanawiali się nad konstrukcjami wiedzy nauczyciela i innych uczniów ${ }^{61}$. W opracowaniu podkreślono, że edukacja we współpracy jest czymś więcej niż formą organizacyjną zajęć. Ponadto, w tak ujmowanej edukacji nie chodzi tylko, jak pisał J. Dewey ${ }^{62}$, o ekonomiczne wartościowanie wytworów pracy grupowej, na przykład wspólnie dojście do wiedzy poprzez rozwiązanie zadania, ukazanie złożoności biografii postaci historycznej, uzgodnienie hipotezy na temat jakiegoś zjawiska. Ważne jest również to, co się dzieje w grupie zadaniowej: interakcje, różnice stanowisk, konflikty oraz próby ich rozwiązania, dialog, dzielenie się wiedzą, negocjowanie wiedzy i reguł społecznych, co stwarza przestrzeń do wymiany intersubiektywnej oraz aktywności zbiorowego umysłu.

\section{BIBLIOGRAFIA}

Appelt K., Dziecko i dzieciństwo w oczach dorostego, [w:] Oblicza dzieciństwa, red. D. Kornas-Biela, Lublin 2001.

Appelt K., Jabłoński S., Osiagnięcia i zagrożenia dla rozwoju dziecka w wieku szkolnym, [w:] Dzieci i młodzież wobec agresji i przemocy, red. A. Brzezińska, E. Hornowska, Warszawa 2004.

Arends R.I., Uczymy się nauczać, przekł. K. Kruszewski, Warszawa 1995.

Babula S., Kraszewski N., Kołodziejczyk J., Salomon-Bobińska K., Nauczanie kooperatywne (uczenie się we wspótpracy) https://www.npseo/pldata/various,files/Sesja\%20 11_9\%20Jakub\%20Kołodziejczyk.pdf.

Baepler P., Walker J.D., Brooks D.Ch., Saichaie K., Petersen Ch.I., A Guide to Teaching in the Active Learning Classroom. History, Research, and Practice, Virginia 2016.

Bąbka J., Zachowania kooperacyjne młodzieży w sytuacjach zadaniowych. Analiza porównawcza młodzieży pełnosprawnej i z różnymi ograniczeniami sprawności, Zielona Góra 2012.

Borsch F., Kooperatives Lehren und Lernen im schulischen Unterricht, Stuttgart 2010.

Bruner J.S., Kultura edukacji, przekł. T. Brzostowska-Tereszkiewicz, Kraków 2006.

Brzezińska A., J. Bruner: prekursor kształcenia wspomagającego rozwój, [w:] Kultura edukacji, Kraków 2006.

Brzezińska A.I., Ziółkowska B., Przed jakimi wyzwaniami stoi dzisiaj szkoła? Studia Edukacyjne, 2012, 27.

Czapiński J., Kapitał społeczny, [w:] Diagnoza społeczna 2007. Warunki i jakość życia Polaków 2007, red. J. Czapiński, T. Panek, Warszawa 2007.

Czapiński J., Kapitał społeczny jako motor rozwoju rozwiniętych, Małopolskie Studia Regionalne, 2010, 1(18).

${ }^{61}$ D.C. Phillips, J.F. Soltis, Podstawy wiedzy o nauczaniu, s. 79.

${ }^{62}$ J. Dewey, Szkoła a społeczeństwo, przekł. R. Czaplińska-Muternilchowa, Warszawa 2005, s. 18; J. Bruner, Kultura edukacji, s. 86. 
Czapiński J. Kapitał społeczny, [w:] Diagnoza społeczna 2013. Warunki i jakość życia Polaków, red. J. Czapiński, T. Panek, Warszawa 2013.

Czapiński J. Kapitał społeczny, [w:] Diagnoza społeczna 2015. Warunki i jakość życia Polaków, red. J. Czapiński, T. Panek, Warszawa 2015.

Dewey J., Demokracja i wychowanie. Wprowadzenie do filozofii wychowania, przekł. Z. Dorszowa, Wrocław 1972.

Dewey J., Szkoła a społeczeństwo, przekł. R. Czaplińska-Muternilchowa, Warszawa 2005.

Drucker P.F., Społeczeństwo pokapitalistyczne, przekł. G. Kranas, Warszawa 1999.

Dudzikowa M., Erozja kapitału społecznego w szkole w atmosferze nieufności, [w:] Kapitat społeczny w szkołach różnego szczebla. Diagnoza i uwarunkowania, t. 2., red. M. Dudzikowa, S. Jaskulska, R. Wawrzyniak-Beszterda, E. Bochno, I. Bochno, K. Knasiecka-Falbierska, M. Marciniak, Kraków 2011.

Dudzikowa M., Ku sprawstwu, wspótpracy i refleksyjności poprzez ich doświadczanie w edukacji szkolnej. Brunerowskie przestanie w praktyce, [w:] Doświadczenia szkolne pierwszego rocznika edukacji, red. M. Dudzikowa, R. Wawrzyniak, Kraków 2011.

Dylak S., Konstruktywizm jako obiecujaca perspektywa w kształceniu nauczycieli, [w:] Wspótczesność a kształcenie nauczycieli, red. H. Kwiatkowska, T. Lewowicki, S. Dylak, Warszawa 2000.

Erikson E.H, Dzieciństwo i społeczeństwo, przekł. P. Hejmej, Poznań 2000.

Gillies R.M., Cooperative Learning. Integrating Theory and Practice, Los Angeles - London New Delhi - Singapore 2007.

Gołębniak B.D., Konstruktywizm moda, "nowa religia” czy tylko/aż interesujaca perspektywa poznawcza i dydaktyczna? Problemy Wczesnej Edukacji, 2005, 1.

Hejnicka-Bezwińska T., Paradygmat pedagogiki instrumentalnej w Polsce (Skutki jego dominowania w badaniach pedagogicznych $i$ kształceniu pedagogów), [w:] Ku pedagogii pogranicza, red. Z. Kwieciński, L. Witkowski, Torun 1990.

Henrich J., The Secret of Our Success. How Culture Is Driving Human Evolution, Domesticating Our Species, and Making Us Starter, New Jersey 2016.

Hill G.W., Group Versus Individual Perfomance: Are N+1 Heads Better Than One? Psychological Bulletin, 1982, 91.

Johnson D.W., Johnosn R.T., Cooperation and Competition: Theory and Research, Minnesota 1989.

Joyce B., Calhoun E., Hopkins D., Przykłady modeli uczenia się i nauczania, przekł. K. Kruszewski, Warszawa 1999.

Kamiński A., Grupowe nauczanie, [w:] Encyklopedia pedagogiczna, red. W. Pomykało, Warszawa 1993.

Karolczak-Biernacka B., Wspótzawodnictwo i wspótpraca w szkole, Warszawa 1987.

Kędzierska J., Grupowa praca uczniów, [w:] Encyklopedia pedagogiczna XXI wieku, red. T. Pilch, Warszawa 2003.

Klus-Stańska D., Polska rzeczywistość - paradygmatyczny taniec św. Wita, [w:] Paradygmaty wspótczesnej dydaktyki, red. L. Hurło, D. Klus- Stańska, M. Łojko, Kraków 2009.

Klus-Stańska D., Dydaktyka wobec chaosu i pojęć i zdarzeń, Warszawa 2010.

Klus-Stańska D., Dyskursy pedagogiki wczesnoszkolnej, [w:] Pedagogika wczesnoszkolna - dyskursy, problemy, rozwiązania, red. D. Klus-Stańska, M. Szczepska-Pustkowska, Warszawa 2012.

Kohlberg L., Mayer R., Rozwój jako cel wychowania, [w:] Spory o edukację. Dylematy i kontrowersje we wspótczesnych pedagogiach, red. Z. Kwieciński, L. Witkowski, Warszawa 1993. 
Kowalik-Olubińska M., Pedagogiczne implikacje założeń konstruktywizmu dla edukacji małych dzieci, [w:] Zaniedbane i zaniechane obszary edukacji w szkole, red. M. Suświłło, Olsztyn 2006.

Koźmiński A., Jak tworzyć gospodarkę oparta na wiedzy? [w:] Strategia rozwoju Polski u progu XXI wieku, Warszawa 2001.

Kruszewski K., Nauczanie i uczenie się rozwiazyywania problemów, [w:] Sztuka nauczania. Czynności nauczyciela, t. 1, red. K. Kruszewski, Warszawa 2005.

Kuhn T., Struktura rewolucji naukowych, przekł. H. Ostromęcka, Warszawa 2001.

Kwiatkowski M., Theis M., Kapitał społeczny. Od metafory do badań, Rocznik Lubuski, 2004, 30.

Kwieciński Z., Mimikra czy sternik? Dramat pedagogiki w sytuacji przesilenia formacyjnego, [w:] Spory o edukację: dylematy i kontrowersje we wspótczesnych pedagogiach, red. Z. Kwieciński, L. Witkowski, Warszawa - Torun 1993.

Kwieciński Z., Socjopatologia edukacji, Olecko-Białystok 1995.

Malewski M., Od nauczania do uczenia się. O paradygmatycznej zmianie w andragogice, Wrocław 2010.

Melosik Z., Pedagogika pragmatyzmu, [w:] Pedagogika. Podręcznik akademicki, t.1, red. Z. Kwieciński, B. Śliwerski, Warszawa 2003.

Muszyński H., Wychowanie moralne w zespole, Warszawa 1964.

Niemierko B., Podręcznik skutecznej dydaktyki, Warszawa 2007.

Oelkers J., Influence and Development: Two Basic Paradigms of Education, Studies in Philosophy and Education, 1994, 2.

Okoń W., Nauczanie problemowe we wspótczesnej szkole, Warszawa 1975.

Ornstein A.C., Hunkins F.P., Program szkolny. Założenia, zasady, problematyka, przekł. K. Kruszewski, Warszawa 1999.

Pawlak B., Praca grupowa w edukacji wczesnoszkolnej. Problemy - badania - rozwiazania, Kraków 2009.

Phillips D.C., Soltis J.F., Podstawy wiedzy o nauczaniu, przekł. E. Jusewicz-Kalter, Gdańsk 2003.

Putnam R.D., Demokracja w działaniu. Tradycje obywatelskie we wspótczesnych Wtoszech, przekł. J. Szacki, Kraków 1995.

Rorty R., Filozofia a nadzieja na lepsze społeczeństwo, przekł. J. Grygieńć, S. Tokariew, Toruń 2013.

Roth W.M., Experimenting in a constructivist high school physics laboratory, Journal of Research in Science Teaching, 1994, 31.

Rutkowiak J., Wielość paradygmatów dydaktyki a wspólny mianownik realności życia. Ku pytaniom o przekłady międzyparadygmatyczne, [w:] Paradygmaty wspótczesnej dydaktyki, red. L. Hurło, D. Klus-Stańska, M. Łojko, Kraków 2009.

Steiner I.D., Group Process and Productivity, New York - London 1972.

Strebe J.D., Enganing Students Using Cooperative Learning, New York 2018.

Szymański M.S., Grupowa praca z uczniem, [w:] Encyklopedia pedagogiczna, red. W. Pomykało, Warszawa 1993.

Szymański M.S., O metodzie projektów, Warszawa 2010.

Śliwerski B., Wspótczesna myśl pedagogiczna. Znaczenia, klasyfikacje, badania, Kraków 2009.

Weidner M., Kooperatives Lernen in Unterricht. Das Arbeitsbuch, Seelze-Velber 2009. 